๑О. В. Булавенко, І. Ю. Коцюбська

Віннищький національний медичний університет ілені М. І. Пирогова

\title{
ОЦІНКА РОЛІ ГЕМОДИНАМІЧНОГО ЗАБЕЗПЕЧЕННЯ МАТКИ В ГЕНЕЗІ ТРУБНО-ПЕРИТОНЕАЛЬНОЇ ФОРМИ БЕЗПЛІДДЯ В ЖІНОК ІЗ ОЖИРІННЯМ У ПРОГРАМАХ ДОПОМГЖНИХ РЕПРОДУКТИВНИХ ТЕХНОЛОГІЙ
}

Мета дослідження - оцінити гемодинамічне забезпечення матки і стан фролікулярного резерву в жінок із безпліддям трубно-перитонеального генезу та з ожирінням 1-2 ступеня як важливі предиктори успішності проведення екстракорпорального запліднення.

Матеріали та методи. При проведенні проспективного дослідження були обстежені 40 пацієнток із трубно-перитонеальною фрормою безпліддя та ожирінням (IMT 30-35). Контрольну групу склали 30 жінок із трубно-перитонеальним фрактором безпліддя та IMT 20-25 кг/м² у програмах допоміжних репродуктивних технологій. Перед включенням пацієнток у програми екстракорпорального запліднення (ЕКЗ) їм проводилось на 2-3-й день менструального циклу ультразвукове сканування 3 доплерометричним картуванням маткових судин.

Результати дослідження та їх обговорення. Проведено дослідження внутрішньоматкової васкуляризації та стану фолікулярного апарату в 40 жінок з трубно-перитонеальною формою безпліддя й ожирінням. Виявлено, що у даної групи жінок відзначалось зниження інтенсивності внутрішньоматкової васкуляризації за доплерометричними показниками ендометріальної персузії (ВШ 5,25, 95 \% ДІ [1,80-15,35], p=0,002). У 25,0 \% пацієнток, зарахованих до програми ЕК3, мав місце обмежений фролікулярний резерв (ВШ 4,11, 95 \% ДІ [1,10-15,29], p=0,035). Ознаки, що були виявлені, можуть бути незалежними кофакторами безпліддя, що можуть зменшити шанси на можливість завагітніти по програмах ЕКЗ.

Висновки. Кофакторами інфертильності, крім основного фактора, могли бути не діагностовані раніше захворювання ендометрія (22,0 \%), гідросальпінкс, полікістозна структура яєчників (10,0 \%), обмежений фролікулярний резерв. Крім того, у пацієнток з ожирінням було діагностовано зниження інтенсивності внутрішньоматкової васкуляризації за доплерометричними показниками ендометріальної перфузії.

Ключові слова: трубно-перитонеальне безпліддя; ожиріння; внутрішньоматкова васкуляризація; сролікулярний резерв; допоміжні репродуктивні технології; екстракорпоральне запліднення.

ОЦЕНКА РОЛИ ГЕМОДИНАМИЧЕСКОГО ОБЕСПЕЧЕНИЯ МАТКИ В ГЕНЕЗЕ ТРУБНО-ПЕРИТОНЕАЛЬНОЙ ФОРМЫ БЕСПЛОДИЯ У ЖЕНЩИН С ОЖИРЕНИЕМ В ПРОГРАММАХ ВСПОМОГАТЕЛЬНЫХ РЕПРОДУКТИВНЫХ ТЕХНОЛОГИЙ

Цель исследования - оценить гемодинамическое обеспечение матки и состояние фолликулярного резерва у женщин с бесплодием трубно-перитонеального генеза и ожирением 1-2 степени как важные предикторы успешности проведения экстракорпорального оплодотворения.

Материалы и методы. При проведении проспективного исследования было обследовано 40 пациенток с трубноперитонеальной фрормой бесплодия и ожирением (ИМТ 30-35). Контрольную группу составили 30 пациенток с трубно-

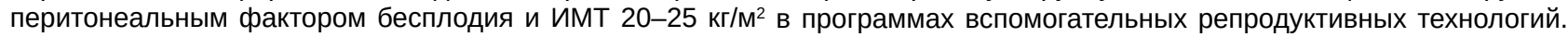
Перед включением пациенток в программы экстракорпорального оплодотворения (ЭКО) им проводилось на 2-3-й день менструального цикла ультразвуковое исследование с допплерометрическим картированием маточних сосудов.

Результаты исследования и их обсуждение. Проведено исследование внутриматочной васкуляризации и состояния фолликулярного аппарата у 40 женщин с трубно-перитонеальной формой бесплодия и ожирением. Выявлено, что у данной группы женщин определялось уменьшение интенсивности внутриматочной васкуляризации по допплерометрическим показателям эндометриальной перфузии (ВШ 5,25, 95 \% ДИ [1,80-15,35], p=0,002). У 25,0 \% пациенток, включенных в программу ЭКО, имел место низкий фолликулярный резерв (ВШ 4,11, 95 \% ДИ [1,10-15,29], p=0,035). Выявленные признаки могут быть независимыми кофакторами бесплодия, которые могут уменшить шансы на возможность наступления беременности в программах ЭКО.

Выводы. Кофакторами инфертильности, кроме основного фрактора, могли быть ранее не диагностированные заболевания эндометрия (22,0 \%), гидросальпинкс, поликистозная структура яичников $(10,0$ \%), ограниченный фролликулярный резерв. Кроме того, у пациенток с ожирением было диагностировано снижение интенсивности внутриматочной васкуляризации по допплерометрическим показателям эндометриальной перфузии.

Ключевые слова: трубно-перитонеальное бесплодие; ожирение; внутриматочная васкуляризация; фолликулярный резерв; вспомогательные репродуктивные технологии; экстракорпоральное оплодотворение.

THE ASSESSMENT OF THE ROLE OF HEMODYNAMIC SUPPORT IN THE GENESIS OF TUBAL-PERITONEAL INFERTILITY IN WOMEN WITH OBESITY TREATMENT BY REPRODUCTIVE TECHNOLOGIES

The aim of the study - to examine a hemodynamic support of uterus and estimate a state follicular reserve in women with a tubal-peritoneal infertility and the 1-2 degree of obesity like the important predictors of the successful pregnancy rate after the invitro fertilisation programes.

Materials and Methods. When conducted prospective study we examined 40 patients with tubal-peritoneal form of infertility and obesity (BMI 30-35). The control group consisted of 30 women with tubal-peritoneal factor infertility and BMI 20-25 kg / m2 in the programs of assisted reproductive technologies. Before turning patients into programs vitro fertilization (IVF) on the $2^{\text {nd }}-3^{\text {rd }}$ of the menstrual cycle day women underwent ultrasound with Doppler mapping of the uterine vessels. 
Results and Discussion. It was studied the intrauterine vascularization and the state of the follicular reserve in 40 women with tubal-peritoneal form of infertility with obesity. It was revealed that in patients of this group of intensity by intrauterine vascularization due to endometrial perfusion parameters had decreased (OR 5.25, $95 \% \mathrm{Cl}[1.80-15.35], p=0.002$ ). In $25.0 \%$ of patients enrolled in the IVF programs was limited follicular reserve (OR 4.11, $95 \% \mathrm{Cl}[1.10-15.29], \mathrm{p}=0.035)$. Symptoms, which were found, may be independent of cofactors for infertility, which can reduce the chances of the possibility of pregnancy in the IVF programs.

Conclusions. Cofactors of the infertility, except of the main factor, could be not diagnosed before diseases of the endometrium (22.0\%), hydrosalpings, polycystic ovarian structure (10.0\%), the limited ovarian reserved. Besides a decline of the intrauterine vascularisation by the doplerometric indices of endometrial perfusion was diagnosed in the patients with obesity.

Key words: tubal-peritoneal infertility; obesity; internal uterine vascularization; follicular reserve; reproduction technologies; invitro fertilization.

ВСтУп. Безпліддя відноситься до важливих показників стану репродуктивного здоров'я. При частоті від 10-15 \% до 18-20 \% можна говорити про прямі репродуктивні втрати $[2,4,5,8]$. Саме тому проблема безпліддя залишається найбільш актуальною в гінекології. Частота безплідних шлюбів у багатьох країнах світу коливається від 8 до $29 \%$ спостережень. В Європі безплідними є близько 10 \%, в США - 15 \%, в Канаді - 17 \% подружніх пар, частка безплідних шлюбів на території України варіює від 8 до $20 \%$ [8, 9]. Також доведено, що саме ожиріння в $6 \%$ випадків є основним фрактором первинного безпліддя. У жінок з ожирінням, навіть 1 ступеня, на $30 \%$ менше шансів завагітніти та на $50 \%$ менше шансів нормально виносити вагітність [13].

Протягом багатьох років у структурі причин жіночого безпліддя значна питома вага - до 50-60 \% - припадає саме на трубний фрактор [2, 7]. 3 огляду на невисоку ефективність методів відновлення природної фрертильності при трубному безплідді [2, 5, 6], найбільш перспективними для його подолання на сучасному етапі визнані допоміжні репродуктивні технології (ДРТ), зокрема екстракорпоральне запліднення (ЕКЗ).

Незважаючи на постійне вдосконалення процедур ЕКЗ, не втрачає своєї значущості пошук шляхів підвищення результативності допоміжних репродуктивних технологій, особливо в жінок із зайвою масою тіла, коли індекс маси тіла (IMT) >30 кг/M² (1-3 ступінь ожиріння), та трубно-перитонеальним фрактором безпліддя. Однією 3 таких можливостей є оптимізація підготовки пацієнток до лікування методом ЕКЗ, вагомий сегмент якої - виявлення та корекція фракторів, що підвищують ризик невдачі.

Причини невдалих спроб ЕКЗ широко вивчаються, причому велике значення надається пошуку причин порушення імплантації. Відомо, що можливість імплантації визначається відповідністю функціональної готовності ендометрія прийняти плідне яйце та здатністю бластоцисти до процесів адгезії та інвазії $[4,6]$. Формування функціонально активного (рецептивного) ендометрія забезпечується множинами фракторів: оптимальним гормональним фоном, задовільними гемодинамічними параметрами в судинній мережі матки, відсутністю хронічного запалення та іншими фракторами $[4,9]$. В основ несприятливого впливу ожиріння на репродуктивну функцію в жінок $є$ порушення гормонального фону, у тому числі збільшення в крові циркулюючих естрогенів. Це підвищує ризик гіперпластичних процесів і тим самим призводить до невдалої імплантації ембріонів у програмах ДРТ.

Також величезну роль у розвитку ендометрія та подальшої імплантації відіграють процеси ангіогенезу - утворення нових кровоносних судин [4]. Ангіогенез протягом менструального циклу має найважливішу роль у процесах росту, формування, дозрівання ендометрія та, таким чином, є одним із ключових моментів, що визначають успіх імплантації та розвитку ембріона [7].

Зниження внутрішньоматкової перфузії обумовлює порушення рецептивності ендометрія. Порушення кровопостачання ендометрія, що розвивається на тлі зривів процесу ангіогенезу, лежить в основі як безпліддя, так й імплантаційних втрат після ДРТ.

Водночас ефективність лікування безпліддя багато в чому залежить від стану оваріального резерву в кожному конкретному випадку. В останні 10 років широко обговорюється поняття «оваріальний резерв» та його значення для вибору методів лікування безпліддя $[1,3]$. Незважаючи на значну кількість робіт, досі не встановлена значимість тих чи інших параметрів у визначенні функціонального стану яєчників при різних формах безпліддя. Раніше використовували термін «фолікулярний пул», визначаючи його кількістю антральних фолікулів в яєчниках $[11,12]$. Однак навряд чи таке визначення можна вважати інформативним, оскільки неінвазивними методами дослідження неможливо повноцінно оцінити фрункціональну повноцінність зростаючих фролікулів. Швидше за все оваріальний резерв визначає функціональний стан репродуктивної системи, повноцінність якої забезпечує зростання, розвиток фолікула, дозрівання ооцита в домінантному фолікулі, овуляцію і запліднення повноцінної яйцеклітини. Стосовно методів стимуляції яєчника повноцінний оваріальний резерв забезпечує адекватну відповідь яєчника на введення індукторів [10]. Отже, оваріальний резерв є важливою складовою частиною репродуктивного потенціалу жінки [1].

У зв'язку з цим особливо актуальним $€$ аналіз дослідження внутрішньоматкової васкуляризації та фролікулярного апарату в жінок при трубно-перитонеальній формі безпліддя, особливо в жінок із зайвою вагою.

МЕТА ДОСЛІДЖЕННЯ - оцінити гемодинамічне забезпечення матки і стан фолікулярного резерву в жінок із безпліддям трубно-перитонеального генезу та з ожирінням як важливі предиктори успішності проведення ЕКЗ.

МАТЕРІАЛИ ТА МЕТОДИ. ПрИ проведенні проспективного дослідження були обстежені 40 пацієнток 3 трубно-перитонеальною формою безпліддя та ожирінням (IMT 30-35). Контрольну групу склали 30 жінок 3 трубноперитонеальним фрактором безпліддя та ІМТ 20-25 кг/м².

Критерії зарахування пацієнтів до основної групи дослідження

- Пацієнтки з трубно-перитонеальною формою безпліддя.

- IMT 30-35 кг/M². 
- Проведена попередня лапароскопічна оклюзія сраллопієвих труб, що перенесли оперативне втручання.

- Не успішні анамнестичні ЕКЗ, що було пов'язано з особливостями лікування.

- Вік пацієнток до 35 років.

- Бажання та можливість брати участь у дослідженні.

- Етнічна однорідність.

Критерії зарахування пацієнтів до контрольної групи дослідження

- Пацієнтки з трубно-перитонеальним фрактором безпліддя

- IMT 20-25 кг/M².

- Проведена попередня лапароскопічна оклюзія фраллопієвих труб.

- Не успішні анамнестичні ЕКЗ, що було пов'язано 3 особливостями лікування.

- Вік пацієнток до 35 років.

- Бажання та можливість брати участь у дослідженні.

- Етнічна однорідність.

Критерії відрахування пацієнтів

- Будь-які клінічно значущі стани, які, на думку дослідника, могли вплинути на безпеку пацієнта, результати оцінок, проведених у рамках дослідження, або порушити процес проведення дослідження.

- Наявні в даний час захворювання або стани, які могли вплинути на інтерпретацію даних з безпеки та ефективності терапії або які є протипоказаннями до неї.

- Наявність інших фракторів жіночого безпліддя.

- Наявність міоми, що десрормує порожнину матки.

- Гострі запальні захворювання репродуктивної сорери.

- Наявність декомпенсованої соматичної патології.

- Відсутність можливості переносу двох ембріонів.

- Відсутність якісних яйцеклітин після пункції фролікулів у програмах ДРТ.

Ультрасонографічний метод дослідження органів малого таза

Усім пацієнтам вироблено дане дослідження в реальному масштабі часу на ультразвуковому апараті HDI 4000 (№ 4703-0037-01 Rev C 2002 (Philips Ultrasound P.O. Box 3003 Bothell WA98041 - 3003 USA)) з використанням конвексного трансдьюсера з частотою 5 Мгц. Оцінювали стан яєчників (їх розміри, положення, стан фролікулярного апарату), також ми визначали наявність спайкового процесу в малому тазу.

При кольоровому доплерівському картуванні (КДК) та вимірювані кровоплину в судинах матки нами була оцінена інтенсивність внутрішньоматкової васкуляризації за характером розподілу кольорових ехосигналів. Судинна система матки була досліджена послідовно, від крупних судин до дрібних (спіральні артерії). При кількісній оцінці КДК були оцінені: пульсаційний індекс (ПІ), індекс резистентності (IP).

Внутрішньоматкова перфузія оцінювалася нами як патологічна при виявленні аваскулярних зон у міометрії та/або ендометрії, при відсутності систолічної або діастолічної складової КДК, підвищенні кут-незалежних індексів та зниженні швидкості кровоплину.

Проводився ультразвуковий моніторинг числа й розмірів фолікулів, а також товщини ендометрія у всіх стимульованих циклах. Предиктором стану фолікулярного резерву була кількість антральних сролікулів до 10 мм у діаметрі, що визначалися за УЗД на 2-3 добу менструального циклу. Залежно від їх кількості виділяли пацієнток 3:

- нормальним фролікулярним резервом - 6-10 фролікулів в обох яєчниках;

- малим фролікулярним резервом - 5 та менше фолікулів в обох яєчниках;

- мультифролікулярними яєчниками - більше 10 фролікулів в обох яєчниках.

Варіаційно-статистичну обробку результатів дослідження було виконано за допомогою програми «STATISTICA 10» Enterprise Portable [2011, ENG] 3 визначенням основних варіаційних показників, таких, як: середні величини (М), середні похибки (m), середньоквадратичні відхилення (p). Достовірність отриманих результатів визначали за допомогою критерію Стьюдента.

РЕЗУЛЬТАТИ ДОСЛІДЖЕННЯ ТА ЇХ ОБГОВОРЕННЯ. На момент дослідження при включенні жінок у програми ДРТ у всіх жінок товщина М-ехо не перевищувала 4 мм та складала в середньому $(3,49 \pm 0,084)$ мм і достовірно не відрізнялася в порівнюваних клінічних групах. Ехометричні параметри матки в порівнюваних групах дослідження відповідали віковим нормам та не мали значущих відмінностей.

Доплерометричні параметри опору судин матки на 2-3 добу менструального циклу (S/D, IR, PI) у маткових та радіальних артеріях достовірно не відрізнялися у жінок обох клінічних груп ( $p>0,05)$.

При трансвагінальній ехограсрії матки на 19-22 день менструального циклу середні показники товщини ендометрія складали $(8,3 \pm 1,2)$ мм у групі жінок з контрольної групи та $(10,7 \pm 2,13)$ мм у жінок з основної групи.

Маткові та радіальні артерії були візуалізовані у всіх пацієнток. Візуалізацію базальних та спіральних артерій, критерії кровоплину в субендометріальному та ендометріальному прошарках, реєстрували не так часто (84,0 \%) (табл. 1).

Таблиця 1. Структура порушень інтенсивності внутрішньоматкової васкуляризації у пацієнток із безпліддям (проспективне дослідження), $\mathrm{n}=100$

\begin{tabular}{|c|c|c|c|c|c|}
\hline \multirow{2}{*}{\begin{tabular}{|l|}
\multicolumn{1}{|c|}{ Групи } \\
Локалізація \\
\end{tabular}} & \multirow{2}{*}{ Інтенсивність перфузії } & \multicolumn{2}{|c|}{ Основна клінічна група (n=40) } & \multicolumn{2}{|c|}{ Контрольна група $(\mathrm{n}=30)$} \\
\hline & & абс. & $\%$ & абс. & $\%$ \\
\hline \multirow[t]{2}{*}{ Міометральна перфузія } & достатня & 34 & 73,3 & 26 & 90,0 \\
\hline & знижена & 6 & 16,7 & 4 & 10,0 \\
\hline \multirow[t]{2}{*}{ Субендометріальна перфузія } & достатня & 22 & 53,3 & 14 & 60,0 \\
\hline & знижена & 2 & 20,0 & 4 & 35,0 \\
\hline \multirow[t]{2}{*}{ Ендометріальна персузія } & достатня & 12 & 20,0 & 18 & 45 \\
\hline & знижена & 28 & 46,7 & 8 & 20 \\
\hline
\end{tabular}


При кольоровому доплерівському картуванні (КДК) було виявлено, що на рівні радіальних артерій інтенсивність васкуляризації була знижена у 16,7 \% та 10,0 \% у жінок з трубно-перитонеальною фрормою непліддя 3 ожирінням та пацієнток 3 нормальною масою тіла відповідно ( $p>0,05)$.

Інтенсивність перфузії у субендометріальному та ендометріальному прошарках також була знижена у пацієнток з ожирінням, при тому, що субендометріальна перфрузія була знижена у жінок з основної групи у $20,0 \%$, а у контрольній групі - у 35,0 \% випадків. При оцінці інтенсивності ендометріальної перфузії впадала в очі різниця у кількості випадків зниженої васкуляризації між обома клінічними групами дослідження. Так, в основній групі зниження перфузії у спіральних артеріях діагностувалося у 46,7 \% випадків, у контрольній групі у 20,0 \%. Таким чином, зазначалася достовірна різниця в інтенсивності ендометріальної перфузії між групами нашого проспективного дослідження (ВШ 5,25, 95 \% ДІ [1,80-15,35], $p=0,002)$.

При підрахунку параметрів кровоплину у базальних та спіральних артеріях привертало увагу зростання показників судинної резистентності у 38,3 \% пацієнток 3 трубно-перитонеальним безпліддям та ожирінням та у $32,5 \%$ жінок 3 контрольної групи (p>0,05). Аналогічні показники у маткових та радіальних артеріях також були підвищені у $16(26,7 \%)$ та $10(16,7 \%)$ жінок в основній клінічній групі й у $10(25,0 \%)$ та 5 (12,5\%) пацієнток 3 контрольної групи відповідно.

При УЗД обстежених пацієнток, крім ознак раніше зазначених супутніх гінекологічних захворювань, що описувались нами у попередньому розділі, вперше був виявлений ряд захворювань, які могли перешкоджати відновленню фрертильності за допомогою програми ЕКЗ (табл. 2).
У 18 (22,0 \%) були діагностовані захворювання ендометрія, міжгрупових відмінностей не виявлено (ВШ 1,22, 95 \% ДІ [0,46-3,24], p=0,69). Ехограсрічна картина полікістозних яєчників мала місце в 6 пацієнток 3 основної клінічної групи $(10,0 \%)$ та у 3 - 3 контрольної групи (7,5 \%), достовірно значущих міжгрупових відмінностей також не було виявлено. У цих жінок динамічна фролікулометрія виявляла картину хронічної ановуляції. У 12 жінок з трубно-перитонеальним безпліддям та ожирінням $(25,0 \%)$ та у $3(7,5 \%) 3$ групи контролю був виявлений гідросальпінкс (ВШ 4,11, 95 \% ДІ [1,10-15,29], p=0,035).

Звертає на себе увагу те, що у 9 (50,0 \%) пацієнток з 15 був гідросальпінкс єдиної маткової труби. До речі, за умовами дослідження усім обстеженим пацієнткам, перед програмою ЕКЗ була виконана лапароскопічна тубектомія.

Вперше виявлена міома матки мала місце у 6,7\% жінок з основної клінічної групи та - 2,5 \% контрольної, у всіх пацієнток сонограсрічно були діагностовані інтрамуральні міоматозні вузли малих розмірів (ВШ 2,79, 95 \% ДІ [0,30-25,88], p=0,37).

Ехографрічні ознаки ендометріозу матки I-II ступеня діагностовано також у 6,7 \% жінок основної клінічної групи та - 5,0 \% контрольної, міжгрупових достовірних відмінностей не виявлено (ВШ 1,36, 95 \% ДІ [0,24-7,78], p=0,73).

Всі пацієнтки з безпліддям, які були зараховані до дослідження, залежно від вихідного стану фолікулярного апарату були розподілені таким чином (табл. 3).

Більшість жінок мала нормальний фолікулярний резерв (в основній групі - у 25 (58,3\%), у контрольній - у 21 (77,5\%), ВШ 0,41, 95 \% ДІ [0,17-1,0], p=0,05. У той час як скудний фролікулярний резерв, за кількістю антральних оролікулів, був діагностований у 10 пацієнток $з$ ожирінням $(25,0 \%)$ та у трьох жінок 3 контрольної групи (7,5\%), ВШ 4,11, $95 \%$ ДI [1,10-15,29], p=0,035.

Таблиця 2. Результати ехографічного дослідження органів малого таза (проспективне дослідження), n=100

\begin{tabular}{|c|c|c|c|c|c|}
\hline Групи & Основ & іа група & Конт & рупа & ВШ (p) \\
\hline Ехографічні ознаки & абс. & $\%$ & абс. & $\%$ & \\
\hline Захворювання ендометрія & 10 & 23,3 & 8 & 20,0 & $1,22,95 \%$ ДІ [0,46-3,24], $(p=0,69)$ \\
\hline Полікістозні яєчники & 6 & 10,0 & 3 & 7,5 & $1,37,95 \%$ ДІ [0,32-5,83], (p=0,67) \\
\hline Гідросальпінкс & 12 & 25,0 & 3 & 7,5 & $4,11,95 \%$ ДІ [1,10-15,29], ( $p=0,035)$ \\
\hline Міома матки & 4 & 6,7 & 1 & 2,5 & $2,79,95 \%$ ДI [0,30-25,88], (p=0,37) \\
\hline Ендометріоз & 4 & 6,7 & 2 & 5,0 & 1,36, $95 \%$ ДІ $[0,24-7,78],(p=0,73)$ \\
\hline
\end{tabular}

Таблиця 3. Стан фолікулярного апарату в жінок із груп проспективного дослідження, n=100

\begin{tabular}{|c|c|c|c|c|c|}
\hline Групи & Основн & на група & $\begin{array}{r}\text { Контрол } \\
(\mathrm{n}\end{array}$ & група & ВШ (p) \\
\hline Ехографічні ознаки & абс. & $\%$ & абс. & $\%$ & \\
\hline Мультифролікулярні яєчники & 5 & 16,7 & 6 & 15,0 & $1,13,95 \%$ ДІ $[0,38-3,41],(p=0,82)$ \\
\hline Обмежений фоолікулярний резерв & 10 & 25,0 & 3 & 7,5 & $4,11,95 \%$ ДІ [1,10-15,29], $(p=0,035)$ \\
\hline Нормативні показники & 25 & 58,3 & 21 & 77,5 & $0,41,95 \%$ ДІ [0,17-1,0], $(p=0,05)$ \\
\hline
\end{tabular}

ВИсновкИ. Проведене ультразвукове дослідження показало, що кофракторами інфертильності, крім основного фрактора, могли бути не діагностовані раніше захворювання ендометрія (22,0\%), гідросальпінкс (ВШ 4,11, 95 \% ДІ [1,10-15,29], p=0,035), яєчники полікістозної структури (10,0 \%).
У 10 пацієнток (25,0 \%), включених до програми ЕК3, мав місце обмежений фолікулярний резерв (ВШ 4,11, 95 \% ДІ [1,10-15,29], p=0,035).

Крім того, у пацієнток 3 ожирінням було діагностовано зниження інтенсивності внутрішньоматкової васкуляризації за доплерометричними показниками 
ендометріальної (ВШ 5,25, 95 \% ДІ [1,80-15,35], p=0,002) перфузії.

ПЕРСПЕКТИВИ ПОДАЛЬШИХ ДОСЛІДЖЕНЬ. Перспективою подальших розробок є розроблення преграві- дарної підготовки для пацієнток з трубно-перитонеальним фактором безпліддя та ожирінням перед включенням їх у програму ЕКЗ.

\section{СПИСОК ЛІТЕРАТУРИ}

1. Тетерина И. В. «Бедный» овариальный ответ в программах ЭКО / И. В. Тетерина, Р. Э. Ванян, Е. А. Калинина // Акуш. и гинек. - 2013. - № 9. - С. 4-12.

2. Онишенко А. С. Бесплодие трубного происхождения: клинический анализ успехов и неудач программы ЭКО / А. С. Онишенко, В. А. Бурлев, Н. А. Ильясова // Проблемы репродукции. - 2013. - № 2. - С. 57-62.

3. Боярский К. Ю. Молекулярные основы фолликулогенеза: от стадии больших антральных фолликулов до овуляции / К. Ю. Боярский, С. Н. Гайдуков // Проблемы репродукции. 2010. - T. 16, № 5. - С. 13-23.

4. Краснопольская К. В. Клинические аспекты лечения бесплодия в браке. Диагностика и терапевтические программы с использованием восстановления методов естественной фрертильности и вспомогательных репродуктивных технологий / К. В. Краснопольская, Т. А. Назаренко. - М. ГЭОТАР-Медиа, 2013. - С. 376.

5. Лызикова Ю. А. Вспомогательные репродуктивные технологии в лечении бесплодия / Ю. А. Лызикова // Охрана материнства и детства. - 2010. - № 2 (16). - С. 80-83.

6. Мишиева Н. Г. Бесплодие у женщин позднего репродуктивного возраста: принципы диагностики и лечения в зависимости от овариального резерва : авторефр. дисс. д-ра мед. наук / Н. Г. Мишиева. - М., 2008. - С. 46.

\section{REFERENCES}

1. Teterina, I.V., Vanian, R.E. \& Kalinina, E.A. (2013). "Bednyi" ovarialnyi otvet $v$ programmakh EKO [The poor ovarial answer in the IVF programs]. Akusherstvo i ginekologia - Obstetrics and Gynecology, 4-12 [in Russian].

2. Onishenko, A.S, Burlev, V.A. \& lliasov, N.A. (2013). Besplodie trubnogo proiskhozhdenia: klinicheskiy analiz uspekhov $i$ neudach programmy EKO [The tubal peritoneal infertility: a clinical analyse of a successes and failure of the IVF program]. Problemy reproduktsii - The Reproduction Problems, 57-62 [in Russian].

3. Boyarskyi, K.Y. \& Gaydukov, S.N. (2010). Molekuliarnye osnovy follikulogeneza: ot stadii bolshykh antralnykh follikulov do ovuliatsyi [The molecular basis of the folikulogenesis: from the grade of a big antral follicle to the ovulation]. Problemy reproduktsyi - The Reproduction Problems, 13-23 [in Russian].

4. Krasnopolskaya, K.V. \& Nazarenko, T.A. (2013). Diagnostika i terapevticheskie programmy s ispolzovaniem vosstanovlenia metodov estestvennoy fertilnosti i vspomogatelnykh reproduktivnykh texnologiy [The diagnostically and therapeutically programs including the methods of the restoration of natural fertility and reproduction technologies]. Moscow: GEOTAR-Media [in Russian].

5. Lyzikova, Y.A. (2010). Vspomogatelnye reproduktivnye tekhnologii $v$ lechenii besplodia [Assisted reproductive technologies of infertility treatment]. Okhrana materinstva i detstva - Protection of Motherhood and Childhood, 80-83 [in Russian].

6. Mishyeva, N.G. (2008). Besplodie u zhenshchyn pozdnego reproduktivnogo vozrasta: printsypy diagnostiki i lechenia $v$ zavisimosti ot ovarialnogo rezerva [The infertility by the women of late reproductive age: the principles of diagnosis and treatment depending on ovarian reserve]. Doctor's thesis. Moscow [in Russian].
7. Коновалова А. В. Трубное бесплодие и экстракорпоральное оплодотворение / А. В. Коновалова, А. А. Соломатина, К. И. Науменко // Российский вестник акушера-гинеколога. - 2011. - № 2. - С. 75-78.

8. Юзько О. М. Використання допоміжних репродуктивних технологій при лікуванні безпліддя в Україні / О. М. Юзько, Т. А. Юзько, Н. Г. Руденко // Збірник наукових праць Асоціації акушерів-гінекологів України. - 2014. - С. 321-324.

9. NICE Clinical Guideline. Fertility: assessment and treatment for people with fertility problems. - London : Royal College of Obstetricians and Gynecologists, 2013. - P. 1-555.

10. Sills E. S. Ovarian reserve screening in infertility: practical applications and theoretical directions for research / E. S. Sills, M. M. Alper, A. P. Walsh // Eur. J. Obstet. Gynecol. Reprod. Biol. - 2009. - Vol. 146, № 1. - P. 30-36.

11. Silva G. M. Number of antral follicles and the success of in vitro fertilization: a multivariate analysis / G. M. Silva, A. L. Diniz, B. M. Neto // Rev. Bras. Ginecol. Obstet. - 2014. - Vol. 23. P. 123-134.

12. Vural B. Hormonal and functional biomarkers in ovarian response / B. Vural, Y. Cakiroglu, F. Vural // Arch. Gynecol. Obstet. - 2014. - Vol. 289, № 6. - P. 1355-1361.

13. The association between severe obesity and characteristics of failed fertilized oocytes / R. Machtinger, C. M. Combelles, S. A. Missmer [et al.] // Hum. Reprod. - 2012. - Vol. 27 (11). - P. 3198-3207.

7. Konovalova, A.V., Solomatina, A.A. \& Naumenko K.I. (2011). Trubnoe besplodie i ekstrakorporalnoe oplodotvorenie [The tubal infertility and invitro fertilization]. Rossyiskiy vestnik akushera-ginekologa - Russian Journal of Obstetrician of Gynecologist, 75-78 [in Russian].

8. Yuzko, O.M., Yuzko, T.A. \& Rudenko N.G. (2014). Vykorystannia dopomizhnykh reproduktyvnykh tekhnolohiy dlia likuvannia bezbliddia $v$ Ukraini [Use of assisted reproductive technologies for treatment of infertility]. Zbirnyk naukovykh prats Asotsiatsii akusheriv-hinekolohiv - Collection of Scientific Works of the Association of Obstetrics and Gynecologists, 321-324 [in Ukrainian].

9. NICE Clinical Guideline (2013). Fertility: assessment and treatment for people with fertility problems, 555. London: Royal College of Obstetricians and Gynecologists [in Great Britain].

10. Sills, E.S., Alper, M.M. \& Walsh A.P. (2009). Ovarian reserve screening in infertility: practical applications and theoretical directions for research. European Journal of Obstetrics Gynecology and Reproductive Biology, 146, 30-36.

11. Silva, G.M., Diniz, A.L. \& Neto B.M. (2014). Number of antral follicles and the success of in vitro fertilization: a multivariate analysis. Rev. Bras. Ginecol. Obstet., 23, 123-134.

12. Vural, B., Cakiroglu, Y. \& Vural, F. (2014). Hormonal and functional biomarkers in ovarian response. Archive of Gynecology and Obstetrics, 289, 1355-1361.

13. Machtinger, R., Combelles, C.M., Missmer, S.A., Correria, K.F., Fox, J.H. \& Racowsky, C. (2012). The association between severe obesity and characteristics of failed fertilized oocytes. Human Reproduction, 27, 207.

Отримано 23.01.17 